\title{
EVIDENCE TYPES AND SURVEILLANCE SYSTEMS IN ANTI-TAX FRAUD MEASURES, ANTI-MONEY LAUNDERING AND COUNTER-TERRORISM FINANCING
}

\begin{abstract}
The goal of this article is to confirm or disprove the hypothesis, whether: "The tax administrators are allowed to use the instruments of evidence which are gained by applying anti-tax fraud methods along with measures of anti-money laundering and counter-terrorism financing only according to the procedural rules of the specific procedure and to the EU data protection rules". It will also discuss the options that the public agencies, including tax administrators and Financial Intelligence Unit, have with regard to using the instruments of evidence, information, documents and tax statements including tax return, control statements and transaction reports received from different subjects via Electronic Registry of Incomes (ERI, EET). This article involves different evidence coming from surveillance systems in Anti-Tax Fraud, Anti-Money Laundering (AML) and in Counter-Terrorism Financing (CTF) according to Tax Procedure Code, Criminal Procedure Code and Administrative Procedure Code along with special legal acts.
\end{abstract}

\section{Key words}

Surveillance Systems; Evidence; Anti-Tax Fraud; Anti-Money Laundering; AML; Counter-Terrorism Financing; Criminal Procedure Code

\section{Introduction}

The goal of this article is to discuss the options that the state has with regard to integrating the evidence, information, documents and tax forms, including tax return, control statements and transaction reports, received from different subjects. The article will confirm or disprove the hypothesis, whether: "The tax administrators are allowed to use the instruments of evidence which are gained by applying anti-tax fraud methods along with measures of anti-money laundering and counter-terrorism financing only according to the procedural rules of the specific procedure and to the EU data protection rules."

It will also discuss the options that the public agencies, including tax administrators, law enforcement agencies and Financial Intelligence Unit, have with regard to using the instruments of evidence, information, documents and tax statements including tax return, control statements and transaction reports, received from different subjects via Electronic Registry of Incomes (ERI, EET). Therefore, I use the concept of public agency instead of tax administrator in some parts of the text because the agencies in the text also involve criminal procedure agencies such as police, state attorney's offices or courts along with tax administration and tax procedure. This article involves different evidence coming from surveillance systems in Anti-Tax Fraud, Anti-Money Laundering (AML) and in Counter-Terrorism Financing (CTF) according to the Tax Procedure Code, Criminal Procedure Code and Administrative Procedure Code along with special legal acts.

It will start in its first chapter "Evidence and Presenting the Evidence" by discussing the evidence and methods of its presenting along with the instruments of proof in the official procedure (which may differ in many countries). These rules will be discussed in general but the Czech regulation will be taken into account as the main basis for anchoring the system. The evidence is given by the instruments of proof which are discussed for example by Macnair [2013, p. 91]. 
The second chapter, "Surveillance Systems in Tax Law" will involve discussion on surveillance in general and on specific deployment of new systems in tax administration which involve collecting the data on income transactions committed to enterprises to the so-called Electronic Registry of Incomes.

The third chapter entitled "Surveillance Systems in AML \& CTF and their Legality for Tax Administration" will include the connected area of measures against money laundering (anti-money laundering) and terrorism financing (counter-terrorism financing) and surveillance systems in these two areas of instruments for protection of the economy and financial system against the misuse of the economic relations. These two types of activities are very dangerous for the economic system itself.

The article will be ended by a Conclusion containing summarising remarks on these areas which have been formulated according to the current legal measures available in evidence and its presence in the Czech law.

\section{Evidence and Presenting the Evidence}

The public agencies including tax administrators, law enforcement agencies and Financial Intelligence Unit possess the access to many resources of evidence with regard to using the instruments of proof, information, documents and tax statements, including tax return, control statements and transaction reports, received from different subjects via Electronic Registry of Incomes (ERI, EET). This article discusses different instruments of evidence coming from surveillance systems in Anti-Tax Fraud, Anti-Money Laundering (AML) and in Counter-Terrorism Financing (CTF) according to Tax Procedure Code, Criminal Procedure Code and Administrative Procedure Code along with special legal acts.

Every procedural legal act usually contains the regulation of the concept: burden of proof, which is defined as "the responsibility for proving something" (according to Cambridge Dictionary) [www.dictionary.cambridge.org (accessed 15.09.2016)]. This burden of proof has to be held by the tax administrator in tax administration, which is allowed to use any documents that may (according to $₫$ 93 of Tax Procedure Code) serve to verify the real face of affairs and to verify the facts decisive for the correct detection and assessment of the tax. It also allows documents and instruments of proof that have been obtained before the beginning of the procedure. There is also a prohibition to use instruments of proof which have been obtained contra legem.

In the regime of administrative procedure, the burden of proof is held by the proponent of a rule or order for the proceedings on the request. For the administrative procedure ex officio, the burden is held by the administrative body administering the proceedings.

This kind of evidence for the successful management of finance management in public sector was discussed by Eigen in the year 2000 [2000, pp. 99-117].

Every instrument of proof has to be dealt with according to the specific procedural legal act. For the tax procedure, the specific act in the Czech Republic is the Tax Procedure Act No. 280/2009 Sb. (Coll.), valid as of 1st January 2011. There is no other lex generalis to the Tax Procedure Act because the Tax Procedure Act is lex generalis itself and at the same time $\$ 262$ of Tax Procedure Act stipulates that it is not possible to use any regulation coming from Administrative Procedure Code on any tax administration processes. The instruments of proof based on the Tax Procedure Act are based on the following evidence types:

- documents (paper or electronic, public and private ones);

- expert opinion;

- witnesses;

- recording duty of the taxable persons (who also create documents);

- aid tools in case of insufficient evidence;

- contract on tax between the Taxable Person and the Tax Administrator;

- preliminary question by the court, administrative body or especially by Court of Justice of the European Union.

For the Anti-Money Laundering and Counter-Terrorism Financing measures, the specific legal act regulating the instruments of proof which come from AML and CTF is the so-called Anti-Money Laundering Act no. 253/2008 Sb. (Coll.) as lex specialis. Lex generalis for the Act no. 253/2008 Sb. (Coll.) is the Administrative Procedure Act no. 500/2004 Sb. (Coll.):

- evidence through documents (also paper or electronic, public and private ones);

- evidence through inspections;

- evidence through witness testimonies;

- evidence through expert opinion;

- preliminary question by the court, administrative body or especially by Court of Justice of the European Union. 
For the Criminal Procedure regarding the Tax Crimes (incl. for example Value Added Tax crimes which are a serious issue in the Czech legal practice), lex generalis which regulates the instruments of proof is the Criminal Procedure Code (as opposed by the Criminal Code itself):

- testimony of the accused, witness testimony and videoconference interrogation;

- confrontation, recognition, investigative experiment and reconstruction;

- on-site verification;

- expert testimony or opinion incl. opinion of the institute;

- evidence by things and documentary evidence;

- inspection incl. inspection of body and inspection of mental state.

As it is visible in the previous lists of instruments of proof, each of the three mentioned legal regimes of instruments of proof contains:

- a type of documentary evidence (documents in tax procedure, evidence through documents in administrative procedure and documentary evidence in criminal procedure);

- evidence based on witnesses and other persons are most general in criminal procedure: testimony of the accused, witness testimony and videoconference interrogation;

- inspections are named in a different way in different procedures - on-site verification in criminal procedure, evidence through inspections in administrative procedure and

- expert opinion (the same name in tax procedure and administrative procedure, expert testimony or opinion incl. opinion of the institute in criminal procedure);

- specific evidence types for criminal procedure involve confrontation, recognition, investigative experiment, reconstruction, videoconference interrogation, evidence by things which are explicitly regulated only in criminal procedures;

- preliminary question is explicitly regulated in the administrative procedure and in the tax procedure, but de facto exists also in criminal procedure although it is not explicitly regulated - in this case preliminary question may be decided by court or by an administrative body;

- specific tax law legal regimes of instruments include recording duty of the taxable persons (who also create documents), aid tools in case of insufficient evidence and contract on tax between the Taxable Person and the Tax Administrator, all three are specifically connected with the nature of the tax administration and tax law (that is collecting public revenues through taxes and other similar pecuniary instruments paid by taxable persons).

According to the Data Protection Act no. 101/2000 Sb. (Coll.) there has to be a title of data processing of a specific data set. The most general title for data processing is the consent of the data subject who is according to Art. 2 letter a) first phrase of the Data Protection Directive no. 95/46/EC (furthermore also as "DPD"): an "identified or identifiable natural person" via the personal data. The consent itself is required by Art. 7 letter (a) DPD, e.g. for classic private relations, enterprise data processing incl. customer relationship management, marketing, etc. The tax procedure incl. anti-tax fraud measures in this type of procedure, along with anti-money laundering and counter-terrorism financing measures and criminal procedure incl. procedure on tax fraud fall under a different title of data processing: Art. 7 letter (e) DPD stating that data processing is allowed when it "is necessary for the performance of a task carried out in the public interest or in the exercise of official authority vested in the controller or in a third party to whom the data are disclosed" [Art. 7 Directive 95/46/EC of the European Parliament]. As of 26 May 2018, currently existing Data Protection Directive will be repealed by the so-called GDPR - General Data Protection Directive which has been passed as the Regulation (EU) 2016/679 of the European Parliament and of the Council of 27 April 2016 on the protection of natural persons with regard to the processing of personal data and on the free movement of such data, and repealing Directive 95/46/ EC (General Data Protection Regulation) [Regulation (EU) 2016/679 of the European Parliament]. Also a new Directive (EU) 2016/680 of the European Parliament and of the Council of 27 April 2016 on the protection of natural persons with regard to the processing of personal data by competent authorities for the purposes of the prevention, investigation, detection or prosecution of criminal offences or the execution of criminal penalties, and on the free movement of such data, and repealing Council Framework Decision 2008/977/JHA has been adopted.

This new framework of personal data regulatory scheme involves the continuation of the previous system of regulation based on the protection of personality rights based on the constitutional rights. 


\section{Surveillance Systems in Tax Law}

Surveillance Technologies are defined by Coleman and McCahill as technologies "operating through plural systems of rule aimed at regulating the movement of goods, persons and the control of criminality" [Lyon 2010, p. 24]. For the purposes of this article, I have simplified Systems of Surveillance Technologies to Surveillance Systems because I believe that the meaning is identical as the previous one. Behind the surveillance systems, there has been a substantial theoretical discussion in sociology and other humanities disciplines on the process of social sorting linked with surveillance, which has been reflected for example by Lyon [2002, pp. 20-22].

The part of gathering evidence on tax evasion is often based on surveillance systems. These systems exist both in anti-tax fraud and in anti-money laundering and counter-terrorism financing. At first, I would like to focus on surveillance systems in tax law. As of 1 December 2016, the Czech Republic introduced a new instrument as a surveillance system per se for collecting the data on transactions and cash / payment card income of enterprises - from this date, restaurants, hotels, hostels, guest houses, cafés, camping sites and canteens.

Electronic Registry of Income is the system that has been introduced into the Czech law according to the Act no. 112/2016 Sb. (Coll.), on the Registry of Income (furthermore as "RI"). This act came into effect as of 1 September 2016 in its part and from 1 December 2016 as a whole. It introduces the concept of "registered income" according to $\$ 4$ part 1 and part 2, which includes the "payment fulfilling formal requirements for a registered income and which forms a basis to decisive income" [ $\$ 4$ part 1 Act no. 112/2016 Sb.]. Second group of registered income involves payments "fulfilling formal requirements for a registered income and is a) dedicated to subsequent drawdown or clearing that both create decisive income, or b) is a subsequent drawdown or clearing that both create decisive income" [ $\$ 4$ part 2 Act no. $112 / 2016 \mathrm{Sb}$.]. It is obvious that this definition has been set out as a definition "in circle", mainly because the Czech version of the act is using different terms "evidovaná tržba" as registered income and "rozhodný př́iem" as decisive income but both "tržba" and "prŕjem" is both translated as income (while revenue which is also sometimes used means a different concept, "výnos", which does not necessarily involve the actual physical payment of the money).

Technically, this system will serve as an Internet reporting system for every payment which has been received according to $₫ 5 \mathrm{RI}$ by an enterprise in cash, by cheque, by bill of exchange, by payment card (which is defined through generally technically-independent definition cashless transfer of money which has been ordered by payer through the beneficiary - taxpayer who is entitled to register the income), in other forms similar to the aforementioned ones and also by netting of bail or guarantee deposited by the aforementioned payment methods. This new regulation was introduced in the same time as the tax package planned for 2017 [Boháč 2016, p. 28], but for many reasons it was submitted into the legislative procedure as a separate act. It was (correctly) expected that this act will be very sensitive in the legislative process, mainly in the Parliament of the Czech Republic.

One of many different arguments against the Electronic Registry of Income has been the violation of fundamental human freedom of "enterprise" granted by Art. 26 part 1 which states "Everybody has ... the right to engage in enterprise and pursue other economic activity" [www.usoud.cz/ en (accessed 15.09.2016)]. This argument was mentioned in the Czech legislative procedure's discussion (having no impact on the fact that the Electronic Registry of Income passed). It is obvious that any type of surveillance in tax administration may diminish the constitutional right to engage in enterprise. But still, in my opinion, the surveillance in an amount which is passed by democratic means, is in compliance with the legal and legitimacy standards given by the constitutional law and the limitation of constitutional rights, is in the limits provided by the Czech Charter of Constitutional Rights and Freedoms. In this case, Art. 26 part 2 of the Charter states that "conditions and limitations may be set by law upon the right to engage in certain professions or activities." In the society of the rule of law, it is usual that one person is limited in its rights and freedoms for the benefits of other persons (on the contrary, the right to judicial and other legal protection is different, because it cannot be limited, it only may have conditions, as it is stated in Art. 36 of the Charter). That means the constitutional shield is limiting and preventing overuse or misuse of the surveillance systems for the purposes outside the legally protected interests of the state.

\section{Surveillance Systems in AML \& CTF and their Legality for Tax Administration}

Automated systems for risk assessment are in the first moment initiated by a bank who is an obliged person 
according to the Act no. 253/2008 Sb. (Coll.) on Anti-Money Laundering and Counter-Terrorism Financing as amended [further only as "AML Act"]. These systems are based on identification of suspicious trades according to the $\$ 6$ of AML Act. The suspicious trades have no specific legislative definition, it is outlined only on the basis of the full enumerative list.

On the basis of the detection of suspicious trades the bank or any other service provider has a duty to report the suspicious trade to the Financial Intelligence Unit. ${ }^{1}$ The Financial Intelligence Unit in Slovakia has a seat in Bratislava and has been founded by the Act no. 297/2008 Z. z. (Coll.) On Anti-Money Laundering and on Counter-Terrorism Financing and on the amendment and supplementation of various legal acts as amended.

This mechanism is a part of the general principle "Know Your Customer" which has been extensively discussed by financial lawyers from Brno Faculty of Law [Kyncl 2012, p.166] currently harmonized by the European Union. As to September 2016, it has been harmonized by the Directive 2005/60/EC of the European Parliament and of the Council of 26 October 2005 on the prevention of the use of the financial system for the purpose of money laundering and terrorist financing. As of 26 June 2017 the Directive (EU) 2015/849 of the European Parliament and of the Council of 20 May 2015 on the prevention of the use of the financial system for the purposes of money laundering or terrorist financing will come into force and be applicable.

With regard to the aforementioned data protection, the lawmaker had an option to let the evidence produced in Anti-Money Laundering and Counter-Terrorism Financing processes to be used in an Anti-Tax Fraud measures in tax administration. According to the Czech legal regulation de lege lata, the amendment of AML Act would be advisable. It is currently unclear because of the construction of a limit on sharing the evidence produced by AML to the tax administration, customs administration and law enforcement agencies. In the past, data protection has been considered mainly the issue for private data processors. The EU regulation shows obvious conclusion - the data processing by public agencies which would be excessive may of course be at the same time harmful to a part of people in the society. It is although obvious interest of the state to allow the tax authorities to be able to tax the data

\footnotetext{
The Czech Financial Intelligence Unit (FIU) is a separate independent department of the Ministry of Finance. In other countries, the legal stance of FIU may vary - e.g. in Slovakia FIU is a department of the Ministry of Interior.
}

which has earlier been gained from the criminal activities. The lawmaker should therefore adopt the amendment to $\$ 32$ part 2 which contains clear jurisdiction of the Financial Intelligence Unit to inform the Police, Financial Administration bodies, Customs Administration Bodies (the latter through General Financial Directorate and General Directorate of Customs) about the facts important for the conduct of activities of these three state bodies. Unfortunately, there is a limitation in $\$ 32$ part 2 to provide only the information which are not in violation for the purpose of the Czech AML Act. It is important to mention the goal of AML Act, which is mentioned in Art. 2 of Recital in Directive 2005/60 as the protection of: "the soundness, integrity and stability of credit and financial institutions and confidence in the financial system... (against) the efforts of criminals and their associates either to disguise the origin of criminal proceeds or to channel lawful or unlawful money for terrorist purposes." That means the effect of the economic system on taxes is the part of the broad goal of the AML Act but is not the primary goal of the AML and CTF regulation.

Despite the mentioned imperfect texting of the AML Act, the source of data and documents in the Anti-Money Laundering and Counter-Terrorism Financing for the benefits of tax administration is expected by the law. The Financial Intelligence Unit usually provides this data and documents to the financial administration and to the customs administration and therefore the texting of the jurisdictional regulation should explicitly mention the ability to disclose the data by Financial Intelligence Unit to the financial and customs administration for tax purposes (which is not regulated in this form, not even with the effectivity as of 1 January 2017 that is in the new legal regulation complying with the aforementioned $4^{\text {th }}$ AML Directive 2015/849/EU).

\section{Conclusion}

The goal of this article was to discuss the options that the public agencies including tax administrators and Financial Intelligence Unit have with regard to using the instruments of proof, information, documents and tax statements, including tax return, control statements and transaction reports received from different subjects via Electronic Registry of Incomes (ERI, EET). I believe that this goal has been met, because the article has partially confirmed and partially disproved the following hypothesis: "The Tax Administrators are allowed to use the 
instruments of proof which are gained by applying anti-tax fraud methods along with measures of anti-money laundering and counter-terrorism financing." The public agencies use the information from surveillance systems for gathering evidence on financial transactions and economic activities that are conducted by taxable persons. The role of the surveillance systems is to obtain specific information and documents that enable upholding the burden of proof ex post in the official procedure, without regard to the fact whether that is a tax procedure, criminal procedure or a special administrative procedure.

\section{Bibliography}

Boháč R. (2016), K problematice tzv. daňových balíčkio. Finanční, daňový a účetní bulletin. č. 3, Wolters Kluwer.

Coleman R., Mccahill M. (2010), Surveillance and crime, London.

Eigen P. a kol. (2000), Kniha protikorupčních strategií, Transparency International, Praha.

Kyncl L. a kol. (2012), Poznej svého klienta - základní zásada finančního práva (Know Your Customer - basic principle of the financial law), 1st ed., Masarykova univerzita, Brno.

Lyon D. (2002), Surveillance as Social Sorting: Privacy, Risk and Automated Discrimination, Abingdon-on-Thames, Routledge.

Macnair M.R.T. (2013), The Law of Proof in Early Modern Equity, "Comparative Studies in Continental and Anglo-American Legal History Series" Volume 20, Berlin: Duncker \& Humblot.

\section{Legal Acts}

Directive 95/46/EC of the European Parliament and of the Council of 24 October 1995 on the protection of individuals with regard to the processing of personal data and on the free movement of such data as amended.

Directive 2005/60/EC of the European Parliament and of the Council of 26 October 2005 on the prevention of the use of the financial system for the purpose of money laundering and terrorist financing as amended.

Directive (EU) 2015/849 of the European Parliament and of the Council of 20 May 2015 on the prevention of the use of the financial system for the purposes of money laundering or terrorist financing.

Directive (EU) 2016/680 of the European Parliament and of the Council of 27 April 2016 on the protection of natural persons with regard to the processing of personal data by competent authorities for the purposes of the prevention, investigation, detection or prosecution of criminal offences or the execution of criminal penalties, and on the free movement of such data, and repealing Council Framework Decision 2008/977/JHA.

Act no. 101/2000 Sb. (Coll.), on Data Protection as amended. Act no. 253/2008 Sb. (Coll.), on Anti-Money Laundering and Counter-Terrorism Financing as amended.

Act no. 297/2008 Z. z. (Coll.) o ochrane pred legalizáciou príjmov $\mathrm{z}$ trestnej činnosti a o ochrane pred financovaním terorizmu a o zmene a doplnení niektorých zákonov v znení neskorších predpisov (On Anti-Money Laudering and on Counter-Terrorism Financing and on the amendment and supplementation of various legal acts as amended).

Act no. 112/2016 Sb. (Coll.), on Registry of Income as amended.

Resolution of the Presidium of the Czech National Council of 16 December 1992 on the declaration of the Charter of Fundamental Rights and Freedoms as a part of the constitutional order of the Czech Republic. Translation provided by the Constitutional Court of the Czech Republic. In: Charter of Fundamental Rights and Freedoms [online] Constitutional Court, www.usoud.cz/en (accessed 15.09.2016).

Regulation (EU) 2016/679 of the European Parliament and of the Council of 27 April 2016 on the protection of natural persons with regard to the processing of personal data and on the free movement of such data, and repealing Directive 95/46/EC (General Data Protection Regulation).

\section{Author biography:}

Libor Kyncl - Assistant Professor for Financial Law and Economics, Department of Law and Social Sciences, Mendel University in Brno, the Czech Republic and Junior Associate in Attorney-in-Law Office of Mgr. Jiří Slováček, Prague. The author specializes in economics for lawyers, financial market law and non-fiscal part of financial law, public expenditures law and law of e-Finance. He is the author and co-author of several books and reviewed articles in law journals, he has also extensively published and presented presentations on conferences since 2007. He is a member of Information and Organization Centre for the Research on the Public Finances and Tax Law in the Countries of Central and Eastern Europe. Website: www.kyncl.net. 